\section{Rosemary Cultivar Ontogeny Affects Success as Potted Christmas Tree Shaped Topiary}

\author{
Daniel F. Warnock ${ }^{1}$ and Charles E. Voigt ${ }^{2}$ \\ University of Illinois, Department of Natural Resources and Environmental \\ Sciences, 1201 South Dorner Drive, Urbana, IL 61801
}

\begin{abstract}
Additional index words. Rosmarinus officinalis, niche market crops, greenhouse herb
\end{abstract} production, topiary shaping

\begin{abstract}
Greenhouse production of rosemary (Rosmarinus officinalis L.) as small potted Christmas tree topiaries for holiday sales has become necessary for many companies marketing to large retail outlets. Topiaries must be sheared multiple times to obtain an acceptable Christmas tree shape. Cultivars vary in physical attributes, suggesting that they may respond differentially to mechanical shearing during production. This study assessed sixteen rosemary cultivars for their potential as potted Christmas tree shaped topiaries. Beginning July 2001, rosemary plants derived from vegetative propagation of shoot tips were provided high fertility and maximum light in a greenhouse. From August to October, plants were pruned monthly for a total of three shearing events. The crop was considered mature on the targeted market date of 5 Dec. Final plant quality was visually assessed using a 1 to 5 scale that accounted for taper, plant-to-pot ratio, canopy density, foliage quality, and overall appeal, with one point being removed for each factor not meeting industry expectations. The cultivars varied in their performance as Christmas tree shaped topiaries with most being unacceptable due to minimal basal branching or excessive leaf burn that negatively impacted shape, taper, and aesthetics. Six of the cultivars, 'Taylor's Blue', 'Herb Cottage', 'Joyce DeBaggio' (Golden Rain), 'Shady Acres', 'Rexford' (Rex), and an unnamed clone, were suitable for commercial use having visual ratings ranging from 3.8 to 4.5. These cultivars had equally healthy foliage with little damage. 'Taylor's Blue', 'Shady Acres', 'Joyce DeBaggio' (Golden Rain), the unnamed clone, and 'Herb Cottage' had foliar damage ratings ranging from 3.3 to 3.8 and were not significantly different from the most healthy cultivars, 'Logee White' (Thinleaf White), 'Salem', and 'Hill Hardy', all of which had mean ratings of 4.0. These cultivars should be examined for additional attributes that may enhance their performance as Christmas tree shaped topiaries.
\end{abstract}

Rosemary (Rosmarinus officinalis L.) is a common garden herb grown in many regions of the world for culinary, medicinal, and aesthetic uses (Voigt, 2000). Outdoor production of rosemary for culinary and medicinal purposes is well documented(Boelens, 1985; Soulier etal, 1996). Rosemary production in greenhouses, while challenging due to insect and disease pressures combined with the need for tight water management (DeBaggio, 1987; Gilbertie, 1987; Long, 1998), is possible with plants most often used as fresh cut herbs or bedding plants for the home landscape (Long, 1998). Recently, Westervelt (2003) found that fertility rates, irrigation frequency, and soilless media impact potted rosemary plants in greenhouse production systems. Rosemary topiaries are less often produced in commercial facilities due to the increased labor and time needed to create these sculpted plants. In folklore, rosemary is often associated with Christmas, being strewn on floors during the holiday season. Recently rosemary has experienced resurgence in popularity as a Christmas

Received for publication 25 June 2004. Accepted for publication 18 Sept. 2004. The authors thank Green Leaf Perennials (Lancaster, Pa.) for the donation of plants.

${ }^{1}$ Associate professor. To whom reprint requests should be addressed; e-mail: dwarnock@uiuc.edu. ${ }^{2}$ Principal research specialist in agriculture; e-mail: cevoigt@uiuc.edu. decoration, specifically as a Christmas tree shaped topiary. This has created specific challenges for commercial herb producers that desire to market potted Christmas tree shaped rosemary topiaries during the holiday season.

Current production practices for rosemary Christmas tree topiaries vary by grower, butcommonly involve shearing the plants several times with hand-held devices to obtain the Christmas tree shape (Warnock, 2004). Commercially produced woody Christmas trees have a $40 \%$ to $90 \%$ taper with a $66 \%$ taper being ideal (Brown et al., tree shaped topiaries.
1991). Taper is the relationship of the width of the topiary to its height and is determined by dividing the width of the tree at its base by tree height and multiplying by 100 (Brown et al., 1991). For potted rosemary Christmas tree shaped topiaries, crop uniformity is essential and most producers target a $60 \%$ to $70 \%$ taper (C. Voigt, personal observation). Taper is impacted by shearing method and device, with mechanical shearing guided by a template or an angled stationary trimmer being more precise than hand trimming without a template (Warnock, 2004).

In addition to shearing method and device, cultivar phenotype is likely to influence topiary quality. Rosemary cultivars are classified as having prostrate or upright growth habits (Voigt, 2000). Prostrate cultivars are often used as potted plants, along the top of walls, or on steep banks due to their trailing nature (Bown, 2001). Many cultivars are described as upright with a sprawling habit (Bown, 2001; Voigt, 2000). These upright cultivars are used as hedges in areas suitable for perennial establishment (Bown, 2001). Upright cultivars with a sprawling habit provide the opportunity to create sculpted topiaries or bonsai (Voigt, 2000). Producers recognize that cultivar selection impacts the aesthetic value of the final topiary of bonsai, with some, such as 'Rexford' (Rex), 'Shady Acres', 'Tuscan Blue', and 'Taylor's Blue', being more suited for standard ball topiary production and others, such as 'Blue Boy', 'Benenden Blue', 'Majorca Pink', and 'Benenden Blue' (Pine), being more suited for multistemmed bonsai (C. Voigt, personal observation). In light of the popularity of rosemary as a Christmas tree shaped topiary, producers are seeking cultivars that rapidly develop into properly shaped potted plants for holiday sales. Many producers of rosemary Christmas tree shaped topiaries use the cultivars, 'Tuscan Blue' or 'Salem', due to the high levels of disease resistance and upright habits (S. Gilbertie, personal communication). Other cultivars that are suggested for Christmas tree shaped topiaries include 'Benenden Blue', 'Logee Blue', and 'Herb Cottage' (D. Hyde and F. DeBaggio, personal communication). These cultivars, however, are produced in much smaller volumes than the two preceding cultivars. In addition, a direct comparison of cultivars for production performance as Christmas tree shaped topiaries does not exist.

Table 1. Cultivar name and source for 16 rosemary genotypes evaluated for potential as potted Christmas

\begin{tabular}{ll}
\hline Cultivar & Source \\
\hline Unnamed clone & Green Leaf Perennials \\
Arp & Green Leaf Perennials \\
Athens Blue Spire & Buffalo Springs Herb Farm \\
Benenden Blue & Well-Sweep Herb Farm \\
Joyce DeBaggio (Golden Rain) & Richters \\
Herb Cottage & Well-Sweep Herb Farm \\
Hill Hardy & H \& H Botanicals \\
Majorca Pink & Well-Sweep Herb Farm \\
Benenden Blue (Pine) & Richters \\
Rexford (Rex) & Richters \\
Salem & Richters \\
Shady Acres & Shady Acres Herb Farm \\
Spice Island & Greenfield Herbs \\
Taylor's Blue & Taylor's Herbs \\
Logee White' (Thinleaf White) & Well-Sweep Herb Farm \\
Tuscan Blue & Well-Sweep Herb Farm \\
\hline
\end{tabular}


Table 2. A visual rating scale based on the aesthetics of market-ready potted Christmas tree shaped topiaries that was used to evaluate sixteen rosemary cultivars. Individual plants were assigned a value of 5 followed by single point deductions for each trait assessed that failed to meet industry expectations for potted crops (Pi Alpha Xi, 1998). Ratings between 5 and 4 were considered commercially acceptable while ratings $\leq 2.5$ were considered unacceptable having less than half of the traits evaluated acceptable.

\begin{tabular}{lc}
\hline Rating & $\begin{array}{c}\text { Commercially acceptable } \\
\text { traits (no. })^{\mathrm{z}}\end{array}$ \\
\hline 1 & 1 \\
2 & 2 \\
3 & 3 \\
4 & 4 \\
5 & 5 \\
\hline
\end{tabular}

${ }^{\mathrm{z}}$ Acceptable taper, plant-to-pot ratio, canopy density, plant health, and overall appeal $=60 \%$ to $70 \%, 2: 1$ to $2.25: 1$, thick canopy that limits light penetration through plant and evenly covers evidence of pruned shoots, no presence of fungal, arthropod, nutritional, or chemical damage, and color, plant size, leaf size, and canopy shape and symmetry combine to create a topiary that mimics a Christmas tree, respectively.

The objective of this study was to determine if rosemary cultivars derived from various breeding programs, when grown with uniform production parameters and shearing techniques, differed in the quality of Christmas tree shaped topiaries produced. The cultivars selected for this study all have upright growth habits but vary in leaf color, leaf size, flower color, and spread. They represent the wide array of rosemary plant types available in the commercial trade.

\section{Materials and Methods}

Stock plants of sixteen rosemary cultivars (Table 1) acquired from commercial nurseries were maintained in glass covered greenhouses in Urbana, Ill. using standard production techniques currently described by Hamrick (2003). Greenhouse temperatures were set at 24 and 16 ${ }^{\circ} \mathrm{C}$ for day and night with ambient irradiance. Terminal cuttings from healthy vegetative shoots were taken from individual stock plants of each cultivar on 18 May 2001, dipped in $0.2 \%$ indole3 -butyric acid (IBA) rooting powder (Hormex \#2, BrookerChemical, NorthHollywood, Calif.), inserted into 72 -cell packs $\left(50 \mathrm{~cm}^{3}\right.$ per cell) containing rooting media ( 1 peat : 1 perlite), and placed under intermittent mist with greenhouse temperatures ranging from 24 to $26^{\circ} \mathrm{C}$. Rooted cuttings were removed from mist on 8 June 2001 and transplanted into $12.7-\mathrm{cm}(1.2-\mathrm{L})$ diameter pots filled with a soilless media (Strong-Lite Universal Mix, Seneca, Ill.) on 5 July 2001. Four pots containing plants with a single strong stem (leader) of uniform height and shape were selected for each cultivar. Thus, each cultivar was represented by four single plant replications to arrive at a total of 64 experimental units.

To promote lateral branching, plants were pinched with 2.5 to $3.75 \mathrm{~cm}$ of terminal growthbeing removed. Plants were placed in a completely randomized design and fertilized as needed with a water-soluble $20 \mathrm{~N}-4.4 \mathrm{P}-16.6 \mathrm{~K}$ (Nutriculture, PlantMarvelLaboratories, Inc., Chicago Heights, Ill.) at $350 \mathrm{mg} \cdot \mathrm{L}^{-1} \mathrm{Nusing}$ an ebb-and-floodbench system (Midwest GROmaster, Inc., St. Charles, Ill.). Fertility was reduced to $100 \mathrm{mg} \cdot \mathrm{L}^{-1} \mathrm{~N}$ during Octoberand November. Plain water leaches were conducted periodically tominimize the possibility of soluble salt build up in the rooting substrate. To prevent flower development, plants were given a night interruption treatment using incandescent lights timed to be on from 22:00 to $03: 00 \mathrm{HR}$ daily during the entire production cycle. Arthropod pests were managed with labeled pesticides as needed, based on yellow sticky card counts and scouting. Due to the susceptibility of rosemary plants to fungal pathogens (Conway et al., 1997; DeBaggio, 1987; Gilbertie, 1987; Voigt, 2000), preventative fungicide drenches or sprays were applied monthly.

Beginning in August, plants were sheared on a monthly basis with a mechanical shearing device (Warnock, 2004) to promote the development of a Christmas tree shape. Three shearing events occurred for each plant with a final shearing $50 \mathrm{~d}$ before the targeted market date of 5 Dec. 2001. Six months after transplanting, each plant was visually rated for market potential using a 1 to 5 scale (Table 2). Each plant was initially given a rating of 5 with one point being deducted for each factor present that reduced market potential. While no quality standards exist for potted rosemary Christmas tree shaped topiaries, standards for potted foliage and flowering crops (Pi Alpha Xi, 1998) were used to determine traits that likely impact topiary quality and market potential. For the current study, the evaluated traits were considered commercially acceptable if the plant taper equaled $60 \%$ to $70 \%$, plant-to-pot ratio equaled 2:1 to $2.25: 1$, canopy limited light penetration through plant and evenly covered the evidence of pruned shoots, plants had no presence of fungal, arthropod, nutritional, or chemical damage, and overall appeal, based on color, plant size, leaf size, and canopy shape/symmetry, combined to create a topiary that mimics a Christmas tree.

Many cultivars expressed a high level of foliar damage. Because this trait was present on most plants, it was excluded from the quality evaluation ratings and was independently evaluated using a 1 to 5 scale where $1=$ complete leaf death, $2=99 \%$ to $60 \%$ of leaf area damaged, 3 $=59 \%$ to $30 \%$ of leaf area damaged, $4=29 \%$ to $1 \%$ of leaf area damaged, and $5=$ no leaf area damaged based on visual estimations of total canopy damage. Data collected on 5 Dec. 2001 were analyzed in a one-way analysis of variance(ANOVA)(SAS 2002), and significant treatment means were separated using Fisher's protected least significant difference(LSD) mean separation test at $P \leq 0.05$.

\section{Results and Discussion}

The topiary quality varied by genotype ( $\mathrm{df}$ $=15, \mathrm{MS}=5.02, \mathrm{~F}=13.12, P<0.001)$ but not replication $(\mathrm{df}=3, \mathrm{MS}=0.18, \mathrm{~F}=0.48, P=$ 0.700 ). The overall mean visual rating of topiary quality was 3.0 but ratings ranged from a high of 4.5 for 'Shady Acres' and "Taylor's Blue' to a low of 1.0 for 'Majorca Pink' (Table 3). Most genotypes had quality ratings that would be considered commercially unacceptable having $>50 \%$ of the traits evaluated being deficient. A rating $>4.0$ was considered commercially acceptable, based on consumer preference for an unblemished product and standards for evaluating floral crop quality (Pi Alpha Xi, 1998). Six cultivars had quality ratings near 4.0 ('Herb Cottage' had a mean rating of 3.8 $\pm 0.25)$ and were considered commercially acceptable, while an additional six cultivars had quality ratings $\leq 2.5$ and were considered commercially unacceptable (Table 3 ). The six genotypes with the highest quality ratings were derived from various breeding programs, indicating that ontogeny impacts cultivar performance (Table 1). None of the six cultivars that were rated as commercially acceptable are commonly produced as a Christmas tree shaped topiary by commercial producers (Table 3 ). The cultivar most commonly grown as a Christmas tree shaped topiary, 'Tuscan Blue', had a low

Table 3. Mean ( \pm SEM) rating of topiary quality and foliar damage in sixteen rosemary cultivars sheared three times during production. Mean visual ratings of quality were determined using a 1 to 5 scale based on the aesthetics of market ready potted Christmas tree shaped topiaries where individual plants were assigned a value of 5 followed by single point deductions for each trait assessed that failed to meet industry expectations. Mean visual ratings of foliar damage were determined using a 1 to 5 scale where $1=100 \%, 2=99 \%$ to $60 \%, 3=59 \%$ to $30 \%, 4=29 \%$ to $1 \%$, or $5=0 \%$ of leaf area damaged, respectively.

\begin{tabular}{lcc}
\hline Cultivar & $\begin{array}{c}\text { Visual rating } \\
(1 \text { to } 5)^{\mathrm{z}}\end{array}$ & $\begin{array}{c}\text { Foliar damage } \\
(1 \mathrm{to} 5)^{\mathrm{z}}\end{array}$ \\
\hline Shady Acres & $4.5 \pm 0.29 \mathrm{a}$ & $3.8 \pm 0.25 \mathrm{ab}$ \\
Taylor's Blue & $4.5 \pm 0.29 \mathrm{a}$ & $3.8 \pm 0.25 \mathrm{ab}$ \\
Joyce DeBaggio (Golden Rain) & $4.3 \pm 0.25 \mathrm{ab}$ & $3.8 \pm 0.48 \mathrm{ab}$ \\
Rexford (Rex) & $4.3 \pm 0.48 \mathrm{ab}$ & $3.0 \pm 0.58 \mathrm{bcde}$ \\
Unnamed clone & $4.0 \pm 0.00 \mathrm{ab}$ & $3.5 \pm 0.29 \mathrm{abc}$ \\
Herb Cottage & $3.8 \pm 0.25 \mathrm{ab}$ & $3.3 \pm 0.48 \mathrm{abcd}$ \\
Salem & $3.5 \pm 0.29 \mathrm{bc}$ & $4.0 \pm 0.41 \mathrm{a}$ \\
Arp' & $2.8 \pm 0.25 \mathrm{~cd}$ & $2.8 \pm 0.25 \mathrm{cde}$ \\
Hill Hardy & $2.8 \pm 0.25 \mathrm{~cd}$ & $4.0 \pm 0.00 \mathrm{a}$ \\
Logee White (Thinleaf White) & $2.8 \pm 0.25 \mathrm{~cd}$ & $4.0 \pm 0.00 \mathrm{a}$ \\
Benenden Blue & $2.5 \pm 0.29 \mathrm{de}$ & $3.5 \pm 0.29 \mathrm{abc}$ \\
Benenden Blue (Pine) & $2.5 \pm 0.50 \mathrm{de}$ & $2.5 \pm 0.29 \mathrm{de}$ \\
Athens Blue Spire & $1.8 \pm 0.25 \mathrm{ef}$ & $2.3 \pm 0.25 \mathrm{ef}$ \\
Spice Island & $1.8 \pm 0.48 \mathrm{ef}$ & $2.3 \pm 0.48 \mathrm{ef}$ \\
Tuscan Blue & $1.8 \pm 0.25 \mathrm{ef}$ & $1.5 \pm 0.29 \mathrm{f}$ \\
Majorca Pink & $1.0 \pm 0.00 \mathrm{f}$ & $2.8 \pm 0.25 \mathrm{ced}$ \\
\hline
\end{tabular}

${ }^{z}$ Values are means \pm SEM of four replications. Means within a column followed by the same letter are not different at $P \leq 0.05$ as determined by Fisher's least significant difference (LSD) test. 
quality rating in this study, indicating that other cultivars may be better suited for this style of production (Table 3). The amount of foliar burn on this cultivar was significant and may have impacted plant growth and development in this trial. The cultivar 'Salem' was identified as the second most popular cultivar for Christmas tree shaped topiaries (S. Gilbertie, personal communication). The quality ratings for this cultivar (mean $=3.5 \pm 0.29$ ) were slightly lower than 'Shady Acres' and 'Taylor's Blue' indicating that this cultivar has potential as a Christmas tree shaped topiary (Table 3 ). The cultivars identified as having acceptable quality ratings may be useful in a production program for Christmas tree shaped topiaries.

Production parameters are likely to impact rosemary Christmas tree shaped topiary quality. The shaping of topiaries must occur several times during the crop cycle. Ideally minimal amounts of tissue should be removed at each shearing (Warnock, 2004) with cuttings removed from the plant canopy to reduce the possibility of disease(S. Gilbertie, personal communication). Mechanical shearing will result in more uniform tapers and plant shape than shearing with handheld clippers (Warnock, 2004). Cultivars with white flowers generally are considered slower growers and may require fewer shearing events than those with blue flowers (S. Gilbertie, personal communication). These parameters are likely to impact final topiary quality.

The amount of burned foliage varied by genotype $(\mathrm{df}=15, \mathrm{MS}=2.30, \mathrm{~F}=4.93, P<0.001)$ but not replication $(\mathrm{df}=3, \mathrm{MS}=0.35, \mathrm{~F}=0.76, P=$ 0.523 ). The overall mean visual rating of foliar burn was 3.2. There were no cultivars that had completely healthy foliage, but the severity of foliar damage varied substantially with 'Logee White' (Thinleaf White), 'Salem', and 'Hill Hardy' having little foliage damage (mean rating $=4.0$ ) and 'Tuscan Blue' having significant damage $($ mean rating $=1.5)($ Table 3$)$. The amount of foliar damage on the two most popular cultivars for Christmas tree shaped topiaries, 'Tuscan Blue' and 'Salem', varied extensively. Nine of the sixteen cultivars had similar levels of foliar damage with ratings between 3.3 and 4.0 (Table 3 ). These cultivars had the least amount of foliar damage and included five of the six cultivars identified as being commercially acceptable when evaluated for topiary quality (Table 3 ). The cultivar 'Rexford' (Rex), while considered a commercially acceptable topiary, had slightly more foliar damage $($ mean $=3.0 \pm 0.58)$ than the least damaged cultivars (Table 3 ). 'Salem' was one of the least damaged cultivars and had a high quality rating indicating this cultivar's potential as a Christmas tree shaped topiary.

Rosemary plants are susceptible to foliar diseases and root rots including Rhizoctonia spp. (aerial blight), Botrytis spp., and powdery mildew (Conway et al., 1997; DeBaggio, 1987; Voigt, 2000). As a proactive measure against these fungal pathogens, preventative fungicide drenches or sprays were applied monthly during production. Subsequent laboratory analysis of plant tissues expressing foliar burn indicated that the fungal pathogens, Rhizoctonia spp. or Botrytis spp were not present or present in small quantities as a secondary infection, respectively
(Plant Disease Clinic, University of Illinois, Champaign.). Additionally, microscopic sections and stains of the root tissues did not reveal a fungal invader, indicating that fungal pathogens were suppressed during production. While the possibility of fungal pathogens causing the foliar damage cannot be ruled out, laboratory analysis indicates that the foliar damage likely was not caused by common fungal pathogens.

Environmental factors, such as excessive heat, poor watering practices, or high soluble salts, may be expressed as leaf necrosis (Dole and Wilkins, 2005). Temperature control was adequately maintained during production to minimize any detrimental effects. Ebb and flood irrigation uniformly supplies water to all potted plants on a single bench. The frequency of watering will vary by crop demands and environmental conditions. Rosemary plants are extremely sensitive to overwatering, watering too frequently, especially as young transplants (DeBaggio, 1987). Westervelt (2003) states that visual symptoms of overwatering in rosemary start as leaf tip browning progressing to complete leaf death. Westervelt (2003) also indicated that larger 'Athens Blue Spire' rosemary plants were produced when available water was not limited. Plants in this experiment were watered when the majority of pots were considered to be light in weight as determined by lifting. As this measure is subjective, the possibility of overwatering impacting foliar damage cannot be excluded.

High fertility rates can impact soluble salt levels in the growing media, especially when ebb-and-flood irrigation is employed (Dole and Wilkins, 2005). Typically, plant stress due to high soluble salts is expressed as a reduction in rootarea followed by wilting and necrosis of leaf tissues (Dole and Wilkins, 2005). Rosemary plants are tolerant to high soluble salt levels; however, optimal growth rates occur under low fertility rates (100 to $200 \mathrm{mg} \cdot \mathrm{L}^{-1} \mathrm{~N} 20 \mathrm{~N}-4.4 \mathrm{P}-16.6 \mathrm{~K}$ ) when electrical conductivity readings, a measure of salt concentration in the media solution, are below 3.0 and $6.0 \mathrm{mS} \cdot \mathrm{cm}^{-1}$, respectively (Westervelt, 2003). Westervelt (2003) also found that roots of 'Athens Blue Spire' rosemary plants were more sensitive to soluble salts than shoots. For the current experiment, electrical conductivity measurements were not conducted during production, but plants were leached periodically. The possibility of high soluble salts negatively impacting plant foliage quality, however, cannot be excluded in the current study.

Ontogeny differentially impacts rosemary cultivar performance as Christmas tree shaped topiaries when grown with uniform environmental and cultural practices. In addition to taper, plant-to-pot ratio, canopy density, plant health, and overall appeal, other factors can impact final topiary quality. Leaf color, leaf shape, basal branching, internode lengths, foliage density, and plant vigor are all factors that vary among rosemary cultivars and are likely to impact performance as Christmas tree shaped topiaries. Rosemary cultivars should be compared for these traits to increase the number of cultivars suitable for Christmas tree shaped topiary production. This will provide producers with additional choices to better suit their production parameters and local market demands for high quality rosemary Christmas tree shaped topiaries.

\section{Conclusions}

Rosemary cultivar ontogeny differentially impacts Christmas tree shaped topiary quality. Six of the cultivars, 'Taylor's Blue', 'Herb Cottage', 'Joyce DeBaggio' (Golden Rain), 'Shady Acres', 'Rexford' (Rex), and the unnamed clone, were suitable for commercial use, having visual ratings ranging near 4.0. These cultivars had equally healthy foliage with little damage. 'Taylor's Blue', 'Shady Acres', 'Joyce DeBaggio' (Golden Rain), the unnamed clone, and 'Herb Cottage' had foliar damage ratings above 3.3 and were not significantly different from 'Logee White' (Thinleaf White), 'Salem', and 'Hill Hardy' all of which had mean ratings of 4.0. The most commonly used cultivar in commercial production of Christmas tree shaped topiaries, 'Tuscan Blue', had a low quality rating and a high amount of foliar damage compared to most other cultivars examined. 'Salem', the second most popular cultivar for topiary production, had high quality ratings and little foliar damage. Thus, the most commonly used cultivars may not be the best choice for producing a high quality Christmas tree shaped topiary with minimal foliar damage. This information is important because it broadens the selection of cultivars suitable for topiary production available to commercial facilities.

\section{Literature Cited}

Boelens, M.H. 1985. The essential oil from Rosmarinus officinalis L. Perfumer and Flavorist 10:21-37.

Bown, D. 2001. New encyclopedia of herbs and their uses. Dorling Kindersley Ltd., London, U.K.

Brown, J.H., W.F. Cowen, Jr., and R.B. Heiligmann. 1991. Ohio Christmas tree producers manual. Ohio State Univ. Agr. Expt. Sta. Bul. 670.

Conway, K.E., N.E. Maness, and J.E. Motes. 1997. Integration of biological and chemical controls for rhizoctonia aerial blight and root rot of rosemary. Plant Dis. 81:795-798.

DeBaggio, T. 1987. Growing rosemary as a holiday pot plant at Christmas. Purdue Univ. Agr. Expt. Sta. Bul. 530:91-95.

Dole, J.M. and H.F. Wilkins. 2005. Floriculture principles and species. 2nd ed. Pearson Education, Inc., Upper Saddle River, N.J.

Gilbertie, S. 1987. Greenhouse production of herbs. Purdue Univ. Agr. Expt. Sta. Bul. 518:66-70.

Hamrick, D. 2003. Rosmarinus, p. 620-621. In: D. Hamrick(ed.). Ball redbook. 17thed. vol. 2. Crop production. Ball Publ., Batavia, Ill

Long, J. 1998. Herbs, p. 253-272. In: V. Ball (ed.). Ball redbook. 16th ed. Ball Publ., Batavia, Ill.

Pi Alpha Xi. 1998. A manual for flower judging 8th ed. Univ. Wisc.-River Falls, River Falls.

Soulier, J.M., P. Mailhebiau, P. Goeb, J. Azemar, and J. L'Hospitalier. 1996. The rosemary dossier. Cahiers de 1'Aromatherapie 2:29-55.

Voigt, C.E. 2000. Rosemary, herb of the year 2000. The Herbarist. 66:4-8.

Warnock, D.F. 2004. Mechanical searing device for potted rosemary Christmas tree topiaries. HortTechnology 14:95-98.

Westervelt, P. 2003. Greenhouse production of Rosmarinus officinalis L. MS thesis. Va. Polytechnic Inst. State Univ., Blacksburg. 